\title{
Nutritional Evaluation of Fruits of Gynochthodes umbellata (L.) Razafim. \& B. Bremer-An Underutilized Edible Fruit Plant
}

\author{
Anjusha Sudhakaran and Gangaprasad Appukuttan Nair* \\ Department of Botany, University of Kerala, Kariyavattom Campus, Thiruvananthapuram, Kerala, 695581, India.
}

\begin{abstract}
Objective: The present investigation aimed to assess the nutritional, mineral profiling and anti-nutritional analysis of Gynochthodes umbellata (Syn. Morinda umbellata), an underutilized edible plant belongs to the family Rubiaceae. Literature perusal reveals that, there are no previous reports on nutritional studies for this valuable fruit. Methods: Nutritional, mineral profiling and anti-nutritional analysis of fruits were carried out. Results: In nutritional analysis, carbohydrates $(6.98 \mathrm{~g} / 100 \mathrm{~g} \mathrm{fw})$, protein $(2.68 \mathrm{~g} / 100 \mathrm{~g}$ $\mathrm{fw})$, crude fat $(0.13 \mathrm{mg} / \mathrm{g} \mathrm{dw})$ and crude fibre $(32.58 \%)$ content were detected. The fruits of G. umbellata, Vitamin C ( $25 \mathrm{mg} / 100 \mathrm{~g} \mathrm{fw})$ was higher when compared to other three vitamin evaluated, Four macro elements and 6 micro elements were also quantified. Conclusion: Nutritional and Anti- nutritional analysis reveals that, the $G$. umbellata fruits could be used as a source of protein, vitamin and minerals and highly recommended for
\end{abstract}

consumption as they contain low amount of the anti-nutrients analysed. This is the first report on nutritional analysis of $G$. umbellata fruit.

Key words: Morinda umbellata, Nutritional analysis, Underutilized edible fruit, Anti-nutritional analysis.

Address for Correspondence:

Prof. Gangaprasad Appukuttan Nair, Assistant professor, Department of Botany, University of Kerala, Kariyavattom Campus, Thiruvananthapuram, Kerala, 695581, India.

Phone no: 09447552783

E-mail: gp@keralauniversity.ac.in

DOI : $10.5530 /$ pj.2016.1.16

\section{INTRODUCTION}

Fruits are widely accepted as a good and important source of nutrients and supplement for food in a world faced with problem of food scarcity. Fruits are very vital portion of an adequate diet and they serve as food supplement, and an appetizer. Wild fruits are potential source of antioxidants, vitamins and minerals and they act as an important source of nutrient to the rural population, and can be act as a source of micronutrients, so knowledge about composition of fruits and their nutrient potentials is imperative. ${ }^{1}$ In most developing nations, numerous types of edible wild plants are exploited as sources of food to provide supplementary nutrition to the inhabitants. ${ }^{2}$ The plants, which are neither grown commercially on large scale nor traded widely, may be termed as underutilized plants. These plants are cultivated or grown wild, traded and consumed locally. In recent years, a growing interest has emerged to evaluate various wild edible plants for their nutritional features. ${ }^{3-4}$

The plant selected for the present study was Gynochthodes umbellata (syn: Morinda umbellata) belongs to the family Rubiaceae is an underutilized plant (Figure 1). Plant distributed in India, Srilanka, China, Japan and North Australia. In India, it is seen in East Bengal, Tamil Nadu and Kerala, especially in sacred grooves. ${ }^{5-6}$ This plant produces large number of fruits which are edible and used in curries in younger stage. ${ }^{7}$ Morinda citrifolia fruit (noni) is the major edible close relative of G. umbellata. M. citrifolia has long history of use as a food in tropical regions throughout the world and has been reported to have a broad range of health benefits. ${ }^{8}$ In recent years, the noni fruit juice has received much attention because of its nutritional and antioxidant properties and has been now accepted widely as a nutraceutical and marketed worldwide. Noni juice is also claimed to relieve inflammation. It is reported to have antibacterial, anti fungal, analgesic, hypotensive, anti-inflammatory and immune enhancing effects. ${ }^{9-11}$ Extensive research has been carried out on $M$. citrifolia (noni), there is a lack of information on the other related species like G. umbellata (Syn. M. umbellata). G. umbellata produces large number of edible fruits but the conception of fruit is very rare. Literature perusal reveals that there is no literature regarding the nutritional analysis of its fruit. Hence the present study on the nutritional value of fruits of G. umbellata is very important as it will definitely help in popularising this underutilized crop from a nutraceutical point of view. Thus the major objectives of this study were nutritional, anti-nutritional and min- eral composition analysis as indication of nutritional values of the fruit of G. umbellata.

\section{MATERIALS AND METHODS}

\section{Fruit collection and storage}

The ripened fruits were collected during April-May from wild grown plant from Kariyavattom Campus of University of Kerala, Thiruvananthapuram, Kerala. The fruits were washed and cleaned with distilled water to remove the surface residues and blotted with tissue paper and one part of fresh ripened fruits were stored at $4^{\circ} \mathrm{C}$ for the evaluation of total carbohydrate, total protein, vitamins, $\mathrm{pH}$ of the juice. The other portion of the ripened fruits was dried in a hot air oven for 24 hours at $45^{\circ} \mathrm{C}$. Then the dried fruits were ground well in a mixer grinder and kept in an air tight bottle and stored at $4^{\circ} \mathrm{C}$ in a refrigerator for the evaluation of crude fibre, fatty acid, crude fat, mineral profiling and anti-nutritional analysis. All chemicals used in the study were of reagent grade, unless otherwise stated.

\section{Nutritional analysis}

The proximate composition including the moisture content and crude fibre were estimated as per the method given by Association of Analytical Chemists. ${ }^{12}$ Total carbohydrates were estimated by the method given by Sadasivam and Manickam ${ }^{13}$, Total protein content were quantified using the method by Lowry et al. ${ }^{14}$ Vitamin A, vitamin C, vitamin $\mathrm{B}_{1}$ and vitamin $\mathrm{B}_{12}$ determined using standard procedures by Deepak. ${ }^{15}$ Crude fibre content and crude fat was estimated by the method given by $\mathrm{AOAC}^{12}$ and for fatty acids quantification the procedure given by Akinyeye et al., ${ }^{16}$ were also evaluated in fruits of G. umbellata. $\mathrm{pH}$ of fruit juice were determined using a $\mathrm{pH}$ meter (Cyberlabs, USA). Total carbohydrate, total protein, vitamins, $\mathrm{pH}$ of the juice were evaluated in fresh fruits and crude fibre, fatty acid, crude fat were conducted in dried fruit powder of G. umbellata.

\section{Mineral profiling (macro and micro elements)}

The powdered dried fruit sample was digested using nitric acid-perchloric acid mixture (4:1) for 24 hours. This was then filtered using Whatman 


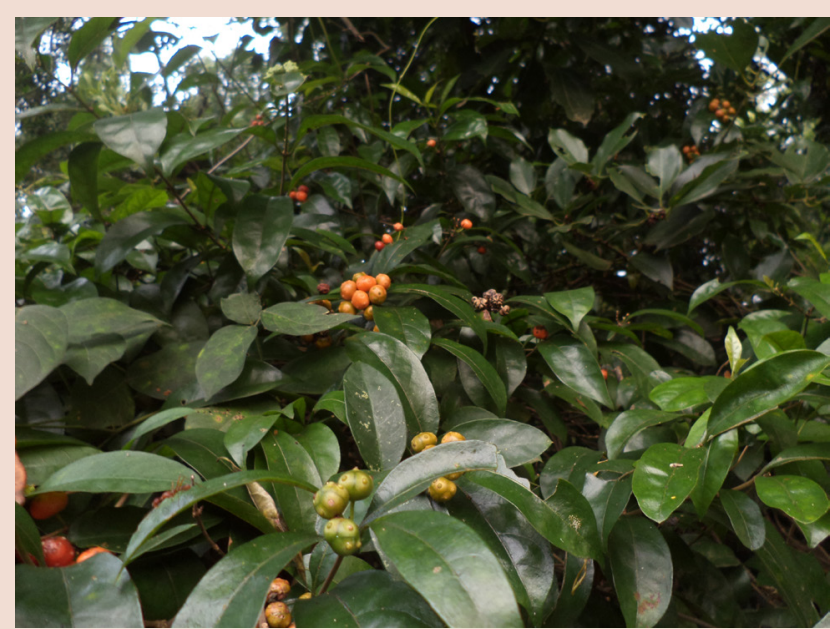

Figure 1: Habit of Gynochthodes umbellata

No. 42 filter paper and the filtrate was used to determine the mineral content using Atomic Absorption Spectroscopy (AAS). ${ }^{17}$ Four macro elements, Magnesium (Mg), Sodium (Na), Calcium (Ca), Potassium (K) and six micro elements like, Iron $(\mathrm{Fe})$, Copper $(\mathrm{Cu})$, Manganese $(\mathrm{Mn})$, Zinc $(\mathrm{Zn})$, Lead $(\mathrm{Pb})$, Cadmium $(\mathrm{Cd})$ were quantified in ripened fruit of G. umbellata.

\section{Anti-nutritional analysis}

The method described by Day and Underwood ${ }^{18}$ was used for the determination of oxalate content. The method described by Cataldo et al., ${ }^{19}$ was adopted in the determination of nitrate. The method reported by Reddy and Love ${ }^{20}$ was used for the determination of phytate. Measurement of saponin concentration of the extract was based on the method described by El-Olemy et al. ${ }^{21}$ All the anti-nutritional parameters were conducted in fresh fruits of G. umbellata.

\section{Anti-nutrient to nutrient molar ratios}

Anti-nutrient to nutrient molar ratios of G. umbellata fruit were also determined by using compare the critical values reported by Hassan et al. ${ }^{22-23}$ Anti-nutrient to nutrient molar ratio helps to predict the effect of anti-nutrient on the bioavailability of mineral elements.

\section{RESULTS AND DISCUSSION}

\section{Fruit collection and storage}

Young fruits of G. umbellata are green in colour (Figure 2), when mature it becomes orange red in colour (Figure 3). The change of fruit skin colour and firmness of fruit which ripen naturally on the plant is represented in Table 1. Fruit contain numerous seeds and were small. The average number of seeds/ fruits were $13.43 \pm 4.43$. The size of the fruits range with an average length of $3.93 \pm 0.84 \mathrm{~cm}$, a width of $2.35 \pm 0.50 \mathrm{~cm}$. The fully ripened fruits were collected for the analysis (Figure 4).

\section{Nutritional analysis}

The nutritional analysis results of G. umbellata were listed in Table 2. The moisture content in fresh fruits (58.32\%) was low when compared to other fruits like Banana (74.91\%), Mango (81\%) and Morinda tinctoria (78.34). ${ }^{24}$ Desai et al.,${ }^{25}$ studied the proximate composition and some physicochemical properties of the two species of Morinda fruits, and observed that the moisture content in M. citrifolia was $63 \%$ and $M$. pubescens was $22 \%$. The low moisture content in the fruit suggests that the levels of other nutrients might be high. ${ }^{26}$

Carbohydrates are one of the most important components in many fruits. The total carbohydrate content in fresh fruits of $G$. umbellata was

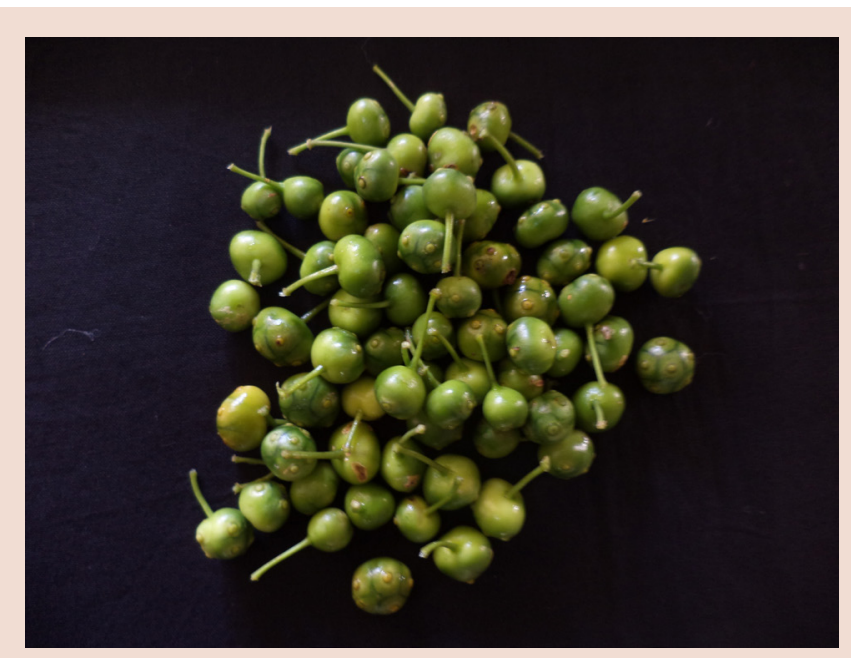

Figure 2: Young fruit of Gynochthodes umbellata

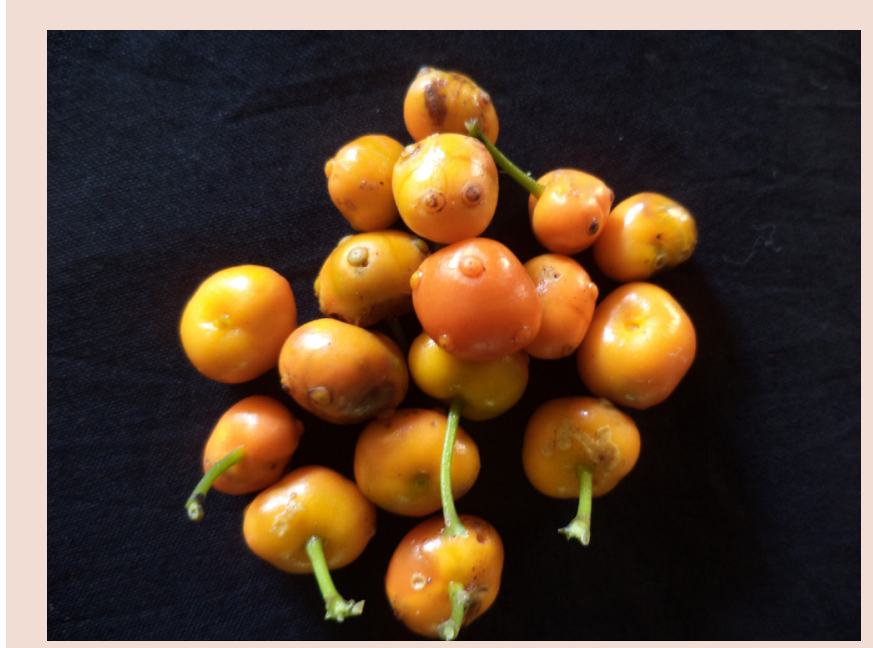

Figure 3: Ripened fruit of Gynochthodes umbellata

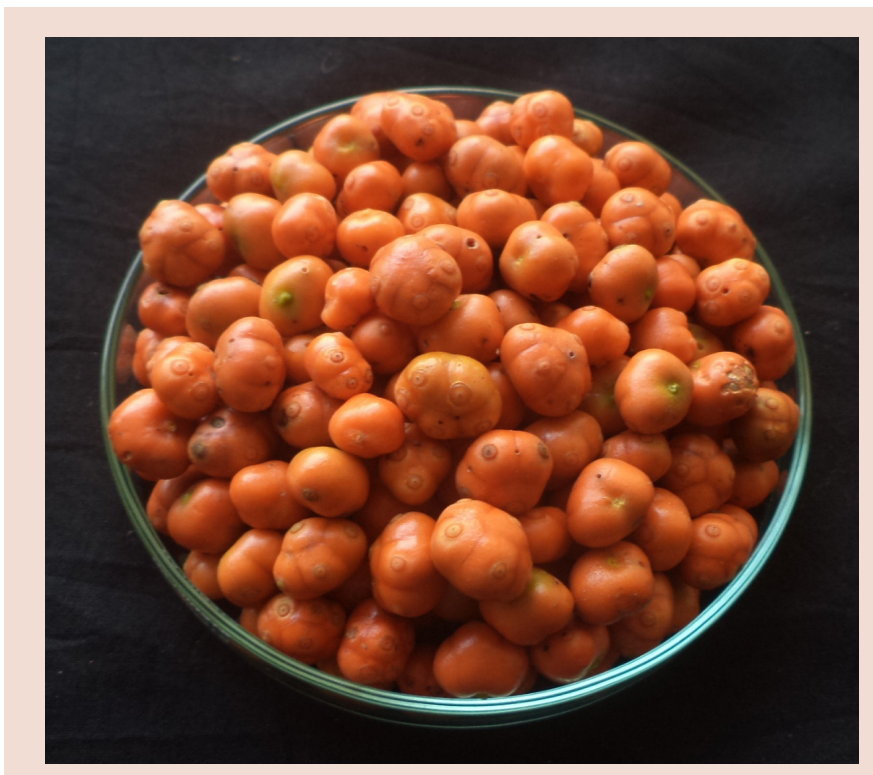

Figure 4: Ripened fruit harvested for analysis 
Table.1: Change of fruit skin colour and firmness in the course of ripening of G. umbellata fruit

\begin{tabular}{ccc}
\hline Maturity stage & Colour & Firmness \\
\hline $\mathbf{1}$ & Dark green & Very hard \\
$\mathbf{2}$ & Dark green & Very hard \\
$\mathbf{3}$ & Green - pale orange & Very hard \\
$\mathbf{4}$ & Orange & Very hard \\
$\mathbf{5}$ & Orange red & Soft \\
\hline
\end{tabular}

Table.2: Nutritional analysis of fruits of G. umbellata

\begin{tabular}{|c|c|}
\hline Nutritional Compound & Concentration* \\
\hline Moisture content (\%) & 58.32 \\
\hline Carbohydrate (g/100g fw) & 6.98 \\
\hline Protein $(g / 100 g$ fw) & 2.68 \\
\hline Crude fat (mg/g dw) & 0.1316 \\
\hline Fatty acid (mg/g dw) & 0.1053 \\
\hline Fibre (\%) & 32.58 \\
\hline Vitamin C (mg/100g fw) & 25 \\
\hline Vitamin A (mg/100g fw) & 1.29 \\
\hline Vitamin $B_{1}(\mathrm{mg} / 100 \mathrm{~g} \mathrm{fw})$ & 0.023 \\
\hline Vitamin $B_{12}(\mathrm{mg} / 100 \mathrm{~g} \mathrm{fw})$ & 0.014 \\
\hline $\mathrm{pH}$ & 4.80 \\
\hline
\end{tabular}

$6.98 \mathrm{~g} / 100 \mathrm{~g}$. This value is comparable with total carbohydrate content reported by Brett ${ }^{27}$ in $M$. citrifolia fruit $(7.21 \mathrm{~g} / 100 \mathrm{~g})$. The protein is another important nutritional factor. G. umbellata fresh fruit have $2.68 \mathrm{~g} / 100 \mathrm{~g}$ protein. Protein is a major source of energy, as well as containing essential amino acids which are important for human being. ${ }^{28}$ Lewis et al. ${ }^{29}$ reported $M$. citrifolia fresh fruit have $5.98 \mathrm{~g} / 100 \mathrm{~g}$ protein. The $M$. citrifolia juice reported to have a lesser amount of protein $(0.4 \mathrm{~g} / 100 \mathrm{~g}) .^{30}$ This reduction in protein may be due to the processing of fruit for the preparation of juice. Crude fat $(0.1316 \mathrm{mg} / \mathrm{g})$ and fatty acid $(0.1053 \mathrm{mg} / \mathrm{g})$ were detected in dried fruits of G. umbellata. In M. citrifolia the crude fat content were reported by various authors, as $0.10 \mathrm{~g} / 100 \mathrm{~g}^{27}$ and $0.14 \mathrm{~g} / 100 \mathrm{~g}^{31}$ were comparable with this result. Low fat foods are considered as preferable. ${ }^{32}$

High fibre content (32.58\%) was detected in G. umbellata dried fruit. High amounts of fibre were also reported in M. citrifolia (33\%) and $M$. pubescens (48\%). ${ }^{33}$ Fibers in diet help the digestion process and aid absorption of trace elements in the intestine. It also reduces the absorption of cholesterol and helps in efficient elimination of wastes. ${ }^{34}$

The Vitamin content of the fresh fruit of G. umbellata reveals high content of Vitamin C (25 mg/100g). Vitamin A (1.29 mg/100g), Vitamin $\mathrm{B}_{1}(0.023 \mathrm{mg} / 100 \mathrm{~g})$ and Vitamin $\mathrm{B}_{12}(0.014 \mathrm{mg} / 100 \mathrm{~g})$ were detected in fresh fruit of G. umbellata (Table 2). European Commission ${ }^{35}$ reported M. citrifolia fruit juice contains $3-25 \mathrm{mg} / 100 \mathrm{~g}$ vitamin C. The $\mathrm{pH}$ of fruit juice of G. umbellata was 4.80. Similar $\mathrm{pH}$ (4.76) was reported in $M$. citrifolia fruit juice $^{36}$ and this $\mathrm{pH}$ fall outside the range that incidentally favours bacterial growth.

\section{Mineral profiling}

The mineral composition is an important for reliable nutrient information and its pivotal role in human life provides healthy growth. ${ }^{37}$ Minerals are essential for normal cellular function and provide additional protection to the human body and act as second messenger in some biochemi- cal cascade mechanisms. ${ }^{38}$ The results of mineral analysis of G. umbellata are depicted in Table 3. Out of four macro elements quantified, potassium $(956 \mathrm{mg} / 100 \mathrm{~g} \mathrm{dw}$ ) was higher followed by calcium $(450 \mathrm{mg} / 100 \mathrm{~g}$ $\mathrm{dw}$ ). The value of potassium is much greater than the popular potassium enriched fruit, banana, with only of $348-370 \mathrm{mg} / 100 \mathrm{~g} .{ }^{39} \mathrm{In}$ addition the fruit also contain substantial amount of Magnesium ( $245 \mathrm{mg} / 100 \mathrm{~g} \mathrm{dw})$, Iron $(3.4 \mathrm{mg} / 100 \mathrm{~g})$, Manganese $(14.1 \mathrm{mg} / 100 \mathrm{~g})$ and Zinc $(1 \mathrm{mg} / 100 \mathrm{~g})$. The Fe and $\mathrm{Zn}$ content of the tropical and sub-tropical fruits ranged from 0.09-3.4 mg/100 g and 0.06-0.64 respectively. ${ }^{39}$ Brett $^{27}$ reported 214.34 $\mathrm{mg} / 100 \mathrm{~g}$ potassium in fresh fruit juice of $M$. citrifolia. All the elements quantified were higher in G. umbellata than the Morinda citrifolia. ${ }^{27}$ This difference in mineral elements is due to the difference in experiment materials used and the difference in plant species. Anuradha et al., ${ }^{37} \mathrm{re}-$ ported the difference in nutrient content in fresh and dry fruits of $M$. tictoria were different.

\section{Anti-nutritional analysis}

Fruits are important sources of minerals, fibre and vitamins, which provide essential nutrients to the human body. But it is known that some fruits have so-called anti-nutritional factors that diminish nutrient bioavailability, especially if they are present at high levels. ${ }^{40}$ The high content of these anti-nutrients exert negative effects on the bioavailability of some mineral nutrient. ${ }^{41}$

\begin{tabular}{|c|c|}
\hline Minerals & Concentration $(\mathrm{mg} / 100 \mathrm{~g} \mathrm{dw})$ \\
\hline \multicolumn{2}{|c|}{ Macro elements } \\
\hline Magnesium (Mg) & 245 \\
\hline Sodium (Na) & 34.1 \\
\hline Calcium $(\mathrm{Ca})$ & 450 \\
\hline Potassium (K) & 956 \\
\hline \multicolumn{2}{|c|}{ Microelements } \\
\hline Iron $(\mathrm{Fe})$ & 3.4 \\
\hline Copper $(\mathrm{Cu})$ & 0.9 \\
\hline Manganese (Mn) & 14.1 \\
\hline Zinc $(Z n)$ & 1 \\
\hline Lead $(\mathrm{Pb})$ & 0.2 \\
\hline Cadmium (Cd) & Not Detected \\
\hline
\end{tabular}

${ }^{\star}$ Each value is an average of 3 determinations.

In G. umbellata oxalate content detected $(1.12 \mathrm{mg} / \mathrm{g})$ is higher than phytate $(0.01 \mathrm{mg} / \mathrm{g})$ and nitrates $(0.018 \mathrm{mg} / \mathrm{g})$. The saponin is absent in G. umbellata fruit (Table 4). Levels of all the anti-nutritional factors in the fruits of $G$. umbellata were lower than the value what can cause mal-absorption of other nutrients, so the consumption of other nutrients should be encouraged when available. ${ }^{1}$

\section{Anti-nutrient to nutrient molar ratios}

Anti-nutrients to nutrients molar ratio are used to predict the effect of oxalate and phytate on the bioavailability of important macro and micro elements. ${ }^{23}$ The Anti-nutrient to nutrient molar ratios were listed in Table 5. All the Anti-nutrient to nutrient molar ratios are below the critical level except [Ca] [Phytate]/[Zn]. This indicate that bioavailability of $\mathrm{Ca}$ and $\mathrm{Zn}$ may be effected by the phytate content which can overcome by little processing of fruit before their consumption.

\section{CONCLUSION}

The present study showed that the underutilized G. umbellata fruits could also be used as a potential source of protein, vitamin and minerals with 
Table. 4: Anti-nutritional analysis of G. umbellata fruit

\begin{tabular}{cc}
\hline Anti- nutritional compound & Concentration $(\mathbf{m g} / \mathbf{g ~ d w})^{*}$ \\
\hline Phytate & 0.01 \\
Oxalate & 1.12 \\
Saponin & Not detected \\
Nitrates & 0.018
\end{tabular}

${ }^{\star}$ Each value is an average of 3 determinations.

Table 5: Anti- Nutrient to Nutrient molar ratios

\begin{tabular}{ccc}
\hline Molar ratio & Value & Critical level* $^{*}$ \\
\hline$[$ Oxalate] $/[\mathrm{Ca}]$ & 0.2489 & 2.5 \\
{$[$ Oxalate $/[\mathrm{Ca}+\mathbf{M g}]$} & 0.1612 & 2.5 \\
{$[\mathrm{Ca}][$ Phytate $] /[\mathrm{Zn}]$} & 4.5 & 0.5 \\
{$[$ Phytate] $/[\mathrm{Ca}]$} & 0.0022 & 0.2 \\
{$[$ Phytate $] /[\mathrm{Fe}]$} & 0.2941 & 0.4 \\
{$[$ Phytate $] /[\mathrm{Zn}]$} & 1 & 10 \\
\hline
\end{tabular}

*(Source: Hassan et al., 2008; Hassan et al., 2011). ${ }^{22-23}$

some of them being even better than $M$. citrifolia and other popular fruits. Anti- nutrient to nutrient molar ratio suggest that little processing is needed before the consumption of G. umbellata fruit. This study suggests more scientific studies should be conducted to identify the nutritional and functional compounds present in G. umbellata fruits and explain their mechanisms of action in order to determine the real potential of this fruit and the technological processes that preserve these. This information is also pertinent to help underutilized and neglected species for better health and nutritional status of the rural communities of the country. The present study also reveals that this fruit can be a substitute for noni.

\section{ACKNOWLEDGEMENTS}

The authors wish to thank Kerala State Council for Science Technology and Environment, Government of Kerala for funding this research work and express our thanks to Professor and Head, Department of Botany, University of Kerala, Kariyavattom, Thiruvananthapuram, Kerala for providing facilities for doing this work.

\section{CONFLICT OF INTEREST}

The authors declare that there are no conflict of interests.

\section{ABBREVIATION USED}

fw: fresh weight, dw: dry weight, $\mathbf{m g} / \mathrm{g}$ : milligram/gram, $\mathbf{c m}$ : centimetre.

\section{REFERENCE}

1. Adepoju OT. Proximate composition and micronutrient potentials of three locally available wild fruits in Nigeria. African Journal of Agricultural Research.2009; Vol. 4 (9): 887-92.

2. Vunchi MA, Umar AN, King MA, Liman AA, Jeremiah G, Aigbe CO. Proximate, Vitamins and Mineral Composition of Vitex doniana (black plum) Fruit Pulp. Nigerian Journal of Basic and Applied Science.2011; 19(1): 97-101.

3. Nazarudeen A. Nutritional composition of some lesser-known fruits used by ethnic communities and local folks of Kerala. Ind. J. Traditional Knowl. 2010; 9(2): 398-402.

4. Aberoumand A, Deokule, SS. Proximate and Mineral Composition of Wild Coco (Eulophia ochreata L.) Tubers in Iran. Asian Journal of Food and Agro-Industry. 2009; 2 (02): 203-9.

5. Vijaya Raghavan G. Comprehensive medicinal plants. Vol. 4. Plant monographs alphabetically, Studium press LIc, Texas, USA; 2011

6. Sasidharan N. Biodiversity Documentation for Kerala. Part 6: Flowering Plants. KFRI Handbook, KFRI, Peechi; 2004
7. Burkill IH. Dictionary of economic products of Malay peninsula. Crown Agents for the Colonies, London; 1953

8. Anuradha V, Praveena A, Sanjayan KP. Nutritive analysis of fresh and dry fruits of Morinda tinctoria. Int.J.Curr.Microbiol.App.Sci 2013; 2(3):65-74

9. Mc Clatchey W. From Polynesian healers to health food stores: changing perspectives of Morinda citrifolia (Rubiaceae). Integral. Cancer Therap. 2002; 1: 110-20.

10. Wang MY, West B, Jensen CJ, Nowicki D, Su C, Palu AK, Anderson G. Morinda citrifolia (Noni): a literature review and recent advances in Noni research. Acta. Pharmacologica Sinica. 2002; 23, 1127-41.

11. Mathivanan N, Surendiran G, Srinivasan K, Sagadevan E, Malarvizhi K. Review on the current scenario of Noni research: Taxonomy, distribution, chemistry, medicinal and therapeutic values of Morinda citrifolia. Int. J. Noni. Res. 2005; 1: 1-16.

12. Association of Official Analytical Chemists. Official methods of analysis, AOAC, 15th edition. Washington DC; 1990

13. Sadasivam S, Manickam A. Carbohydrates. In: S. Sadasivam, A. Manickam (Eds.), Methods in Biochemistry, New Age International Private Limited, New Delhi pp. 11-12; 1996

14. Lowry $\mathrm{OH}$, Rosebrough NJ, Farr AL, Randall RJ. Protein measurement with Folin Phenol reagent. J Biol Chem 1951; pp.193: 265.

15. Deepak K. Trace element analysis and vitamins from an Indian medicinal plant nepeta hindostana (Roth) Haines. International Journal of Pharmacy and Pharmaceutical Sciences 2011; 3 (2):

16. Akinyeye RO, Oluwadunsin A, Omoyeni A. Proximate, mineral, anti-nutrients and phytochemical screening and amino acid composition of the leaves of Pterocarpus mildbraedi Harms. In: Electronic Journal of Environmental, Agricultural and Food Chemistry 2010; (8): 1322-33.

17. Allen SE, Grimhaw HM, Parkinson JA, Quarmby C. Chemical analysis of ecological materials. Edited by Allen SE, Blackwell scientific Publications: Oxford London, Edinburgh, Melbourne, pp. 565;1894

18. Day RA, Underwood AL. Quantitive analysis. 5th ed. Prentice. Hall publication pp. $701 ; 1986$

19. Cataldo et al. Rapid colorimetric determination of nitrate in plant tissues by nitration of salicylic acid. Commun. Soil Science and Plant Analysis. 1975;6(1) 71-80.

20. Reddy MB, Love M. The impacts of food processing on the nutritional quality of vitamins and minerals. Adv. Exp. Med. Bio. 1999; 459: 99-106.

21. El-Olemy, MM, Al-Muhtadi FJ, Afifi AA. Experimental Phytochemistry: A Laboratory Manual. King Saud University Press; 1994

22. Hassan LG, Dangoggo SM, Umar KJ, Sa'idu I, Folorunsho FA. Proximate, Minerals and Anti-nutritional Factors of Daniellia oliveri Seed Kernel. Chem class Journal. 2008; 5: 31-6.

23. Hassan LG, Umar KJ, Dangoggo SM, Maigandi AS. Antinutrient Composition and Bioavailability Prediction as Exemplified by Calcium, Iron and Zinc in Melocia corchorifolia Leaves. Pakistan Journal of Nutrition. 2011; 10(1): 23-8.

24. Ajay KM, Satarupa M, Uday CB, Pratap CP. Nutrient Analysis of Some Selected Wild Edible Fruits of Deciduous Forests of India: an Explorative Study towards Non Conventional Bio-Nutrition. Advance Journal of Food Science and Technology. 2012; 4(1): 15-21.

25. Desai N, Gaikwad DK, Chavan PD. Proximate composition and some physicochemical properties of Morinda pulp. Int. J. Applied Bio. Pharma. Tech. I. 2010; (2):679-82.

26. Nwamarah JU, Chikwendu JN, Otitoju GTO, Eme P. Nutrient, Anti-Nutrients and Phytochemical Compositions of Bosquiae angolensis Fruits "oze" Consumed as Snacks in Enugu State, Nigeria. Pakistan Journal of Nutrition. 2015; 14 (5): 269-73.

27. Brett JW, Shixin D, Jarakae CJ. Nutrient and phytochemical analyses of processed noni puree. Food Research International. 2011; 44 :2295-2301

28. Umi kalsum HZ, Mirfat AHS. Proximate composition of Malaysian underutilized fruits. J. Trop. Agric. Food. Sci. 2014; 42: 63-72

29. Lewis L, Lidianys M, Iloki A, Simon B, Rivera-Castañeda, Elba G, Gil- Salido, Armida A, Acosta-Silva, Ana L, Meza-Cueto, Cipactli Y, Rubio-Pino, José L. Nutritional and Phenolic composition of Morinda citrifolia L. (Noni) fruit at different ripeness stages and seasonal patterns harvested in Nayarit Mexico. International Journal of Nutrition and Food Sciences. 2014; 3(5): 421-9

30. Shovic AC, Whistler WA. Food sources of provitamin A and vitamin $C$ in the American Pacific. Tropical Science. 2001; 41, 199-202.

31. Satwadhar PN, Deshpande HW, Syed IH, Syed KA. Nutritional composition and identification of some of the bioactive components in morinda citrifolia juice. International Journal of Pharmacy and Pharmaceutical Sciences. 2011; 3(1)

32. Gordon MN, Kessel M. Perspective in Nutrition. 5th edition, McGraw Hill Company: Ohio, New York. 2002; 257-281.

33. Desai N, Gaikwad DK, Chavan PD. Proximate composition and some physicochemical properties of Morinda pulp. Int. J. Applied Bio. Pharma. Tech. I. 2010; (2): 679-82.

34. Kelsay JL. Effects of diet fibre on bowel function and trace mineral balances of 
human subjects. Cereal Chem 1981; pp: 2-5.

35. European Commission. Scientific Committee of Food. Opinion of the Scientific Committee on Food of Tahitian Nonis Juice. SCF/CS/ DOS/18 ADD 2. Belgium; 2002

36. Anugweje KC. Proximate Analysis of a commercial Morinda citrifolia juice and a Popular blackcurrant fruit Juice commonly used by Athletes in Nigeria. Academia Arena.2014; 6(12)

37. Anuradha V, Praveena A, Sanjayan KP. Nutritive analysis of fresh and dry fruits of Morinda tinctoria. Int.J.Curr.Microbiol.App.Sci 2013; 2(3): 65-74.

38. Antia RJ, Akpan EJ, Okon PA, Umoren IU. Nutritive and anti nutritive evaluation of sweet potatoes (Ipomoea batatus) leaves. Pak. J. Nut. 2006; 5: 166-8.
39. Yahia EM, J De Jesus J, Ornelas-Paz, Gonzalez GA, Aguilar. Nutritional and health promoting properties of tropical and subtropical fruits. In: EM Yahia (ed.) Post harvest Biology and Technology of Tropical and Subtropical Fruits. Woodhead publishing Series in Food Science, Technology and Nutrition, Cambridge UK, 2011; pp 21-78.

40. Aberoumand A, Deokule, SS. Proximate and Mineral Composition of Wild Coco (Eulophia ochreata L.) Tubers in Iran. Asian Journal of Food and Agro-Industry. 2009; 2 (02): 203-9.

41. Agbaire PO, Emoyan OO. Nutritional and Anti-nutritional Levels of some Local Vegetables from Delta State, Nigeria. African Journal of Food Science. 2012; 6(1): 8-11.
PICTORIAL ABSTRACT

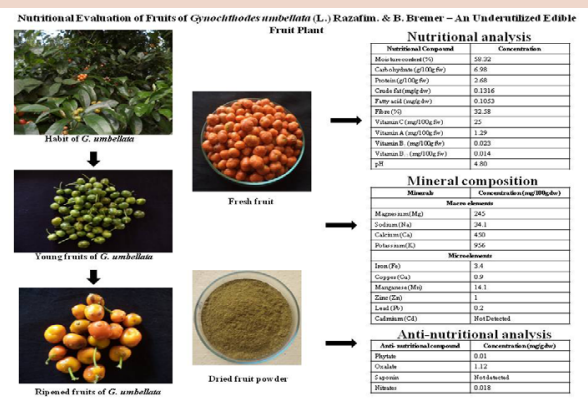

\section{SUMMARY}

- This is the first report on nutritional evaluation of G. umbellata, an underutilized edible fruit plant belongs to the family Rubiaceae.

- Nutritional, mineral profiling were studied using standard procedures and find that this plant have high nutritional value.

- The present study showed that the underutilized G. umbellata fruits could also be used as a potential source of protein, vitamin and minerals.

- Morinda citrifolia (noni) is the major edible close relative of G. umbellata. The present study reveals that this underutilized fruit plant has potent nutritional value and can be a substitute for noni.

- This information is also pertinent to help underutilized and neglected species for better health and nutritional status of the rural communities of the country.

\section{ABOUT AUTHOR}

Dr. A. Gangaprasad: Got his Ph. D. in Botany from Tropical Botanic Garden and Research Institute, Palode at University of Kerala in 1997. Dr. A. Gangaprasad has 22 years of research experience in the field of Conservation Biodiversity and has long experience in the area of Plant Biotechnology. Dr. A. Gangaprasad has made substantial contribution in the areas of conservation Biology, Plant Tissue culture, plant Taxonomy and phytochemistry. 